\title{
KUHINAA SIENIMETSÄSSÄ
}

YRJÖENGESTRÖM(2004). Ekspansiivinen oppiminen ja yhteiskehittely työssä. Vastapaino. (175 s.)

Liian kanssa on ainakin äkkiseltään katsottuna toiminta tämän päivän työympäristöissä enemmänkin touhuamista ja koheltamista. Ja tohinan keskellä uupuvat kanssaihmiset selailevat lehtien minne mennä -palstoja löytääkseen jälleen uusia kohteita pakomatkoilleen arjen paineista.

Mistään touhuamisesta tai koheltamisesta ei kuitenkaan ole kyse kun toiminnasta puhutaan toiminnan teorian ja erityisesti kehittävän työntutkimuksen kielipelin puitteissa. Toiminta on kohteellista, mutta menomestamarkkinoinnin tarjoamat päämäärät ovat pikemminkin korvikekohteita ihmisten luontaisessa pyrkimyksessä ottaa työnsä yhä laajemmin haltuun. Näiden käsitteiden teoreettisen tarkkarajaisuuden tarpeellisuudesta ei Yrjö Engeström tingi viimeisimmässäkään kotimaankielisessä kirjasessaan.

Vastapainon julkaisema teos näyttäisi edustavan tinkimättömyydessäänkin hieman uutta kehittävän työntutkimuksen koulukunnan kirjoittelugenressä. Arkiymmärrys saa edelleen huutia, mutta jonkinlaista kypsymistä kirjassa on aistittavissa sen monissa avauksissa ja toteamuksissa niiden kesken- eräisyydestä, alustavuudesta, hypoteettisuudesta. Ehkä juuri tällaista ajattelun huokoisuutta, jota nyt "aikuisuutensa kynnykselle" tullut toiminnan teorian kotoinen kehittely osoittaa, on oman ymmärryksensä arkisuudesta syyllistynyt lukijakunta kovasti odottanut.

Kirja koostuu pääosin Engeströmin aiemmin julkaistuista artikkeleista, mutta käsittää myös lyhyempiä ideakehittelyä avanneita puheenvuoroja erilaisista yhteyksistä. Engeström luonnehtii kirjaa retkiksi sienimetsään, koko maastoa ja sen sienilajeja kirja ei kata. Artikkelit nostavat erityisesti esille teorian ekspansiivisesta oppimisesta, ajatuksen yhteiskehitte- 
lystä työn uudenlaisena organisointimuotona ja siirtovaikutuksen aikaansaajana sekä fokusoinnin puheeseen ja vuorovaikutukseen kehittävän työntutkimuksen uusimman aallon kohteina. Teksteihin on Engeström kiintoisasti kirjoittanut ajoittavat ja paikantavat opastukset.

Upeasti Engeström käy kirjassa läpi oman ajattelunsa kehitystä seitsemästä veljeksestä uudempaan metodiseen otteeseen, jolla keskustelujen analyysit paljastavat työkäytäntöjen auttamattomia puutteita, ja jossa "neuvotteleva solmutyöskentely” lopulta tarjoutuu yhteiskehittelyä vaativan todellisuuden työmetodiksi. Yhdessä puheistaan hän toteaa, että ”en olisi kehittävä työntutkija, ellen näkisi omassa toiminnassamme ristiriitaa ja haastetta, jotakin mikä ärsyttää etsimään oman tutkimuksen lähikehityksen vyöhykettä”.

Hieman saattaa suoraviivaisemmin ajattelevaa lukijaa omalla tahollaan ärsyttää keskustelun analyyseistä tuttu arkipuheen tai järjenkäytön merkityksellistäminen. Ainakaan maallikon mielestä ei ole kovin järisyttävä "ratkaisuinnovaatio", jos oikeustapauksen tuomari pirauttaa kantajan asianajajalle varmistaakseen, aikooko tämä tuoda todistajia istuntoon vai ei. Kyse tuntuu olevan enemmänkin siitä, mitkä ovat tuomarin tilannekohtaiset intressit ja mahdollisten sanktioiden määrittämä liikkumavara oman työn järkiperäisessä hoitamisessa. Sallittaneen tässä asiaan kohdistuvan tutkimuksen kuitenkin verkkaisesti etenevän omalla lähikehityksen vyöhykkeellään.

Itse tutkimusotteeseen jo vihkiytynyttä lukijakuntaa im- ponoivat ehkä eniten purevat ja ajankohtaiset kommentaarit laatuajatteluun ja konstruktivismiin, mutta myös vertaukset sienimetsään ja muurahaispesän kuhinaan. Kasvatuksen ja kulttuurin vertaamisen hallittuun ja hoidettuun puutarhaan Engeström mieluummin korvaisi vertauksella sienimetsään, jossa rihmastot leviävät laajalla alueella, sivusuunnassa ja ilman määärätietoista hoitamista. Kaoottisena näyttäytyvä työtoiminnan maailma saattaisi toisaalta ehkä olla enemmänkin kuhinaa, joka muistuttaa muurahaispesän mielivaltaiselta näyttävää liikettä - tai skeittajien ärsyttävää tapaa kokoontua yhteen ja hajautua milloin missäkin. "Kuhina on käynnissä, halusimme tai emme", toteaa Engeström oraakkelimaisesti.

Henkilökohtaisen ja yhteisen välimaastoksi otsikoidussa luvussa Engeström toteaa, että "20 vuotta sitten meillä oli visio, kannustava idea”. Innostuksen lisäksi tarvittiin kuitenkin "kurinalaisia aineiston kokoamisen ja analyysin menetelmiä, luotettavuutta ja tarkkuutta”, koska nousevan tutkimusotteen piti myös kestää tiedeyhteisöjen kritiikki. Tie siivoustyön kehittämiseen tähdänneistä analyyseistä kansalliseksi metodologiaksi ei ilman tätä varmaankaan olisi onnistunut. Kiintoisaa vain olisi pohtia, missä määrin tämä tarve hankkia tiedeyhteisön legitimoima asema, on vaikuttanut kehityksen mahdollisuuksia etsivän "romantti- sen tieteen” myöhempään metodologiseen potentiaaliin.

Kirjan kunnioitettavan monilukuisten viittausten ohella Engeström taitaa samalla rajata toiminnanteorian koulukunnan yhä moniäänisemmäksi käyneestä kirjoittelusta legitimoitavaksi kelpaavien innovaatioiden piiriä. Viime vuosien metodologinen ekspansio ammatillisen koulutuksen kenttään, oppilaitosten ja työelämän rajanylitysten maastoon jää lopulta aika ohuen viittauksen varaan. Onko ehkä niin, että sienimetsän rihmastoista kasvaneet tuotokset ovat yllättäneet puutarhurin.

Engeströmin suurin huoli on kuitenkin globaalilla tasolla, uusliberalistisessa välinpitämättömyydessä, joka tarjoaa maaperän häikäilemättömälle voimavarojen väärinkäytölle ja saalistukselle. Tässä eivät arvosteleminen, vastusteleminen tai tuomitseminen auta - ne ovat kehitystä hakevan tutkimusotteen näkökulmasta "perinteisiä keinoja”. Toiminnan teoria ja kehittävä työntutkimus sen sijaan saattavat tarjota asiantiloista huolta kantaville uudenlaisten keinojen varantoa.

Ainakin tämä kirjanen kiteyttää verraten lukijaystävällisesti keskeiset teoreettiset teesit ja metodologiset avaukset. Tekoihin se ehkä ei opasta, mutta toimintaan kenties innoittaa: "This way is up”.

\section{Hannu Valkama}

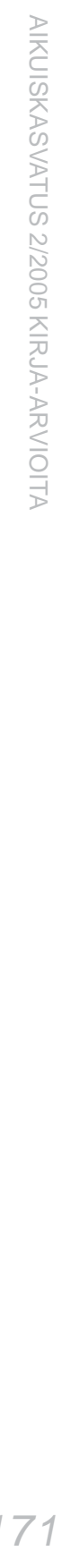

